\title{
KONFERENCA SLOVENŠČINA NA SPLETU IN V NOVIH MEDIJIH
}

\author{
Darja FIŠER \\ Filozofska fakulteta Univerze v Ljubljani
}

Fišer, D. (2015): Konferenca Slovenščina na spletu in v novih medijih. Slovenščina 2.o, 3 (2): $51-53$.

URL: http://www.trojina.org/slovenscina2.o/arhiv/2015/2/Slo2.O_2015_2_o3.pdf.

Od 25. do 27. novembra 2015 je v dvorani GIAM ZRC SAZU v Ljubljani potekala znanstvena konferenca Slovenščina na spletu in v novih medijih. Konferenco so $\mathrm{v}$ okviru temeljnega raziskovalnega projekta JANES, ki ga med letoma 2014 in 2017 financira Javna agencija za raziskovalno dejavnost Republike Slovenije, soorganizirali Filozofska fakulteta Univerze v Ljubljani, Slovensko društvo za jezikovne tehnologije, slovenska raziskovalna infrastruktura za jezikovne vire in tehnologije CLARIN.SI in regionalna iniciativa za jezikovne podatke RelDI.

Prvi dan konference je bil namenjen celodnevnemu seminarju iz statistike za jezikoslovce, ki ga je vodila doc. dr. Maja Miličević z Univerze v Beogradu. 25 udeležencev se je seznanilo z osnovami kvantitativnih metod v korpusnem jezikoslovju, opisno in inferenčno statistiko, prav tako pa tudi $\mathrm{z}$ načini vizualizacije jezikovnih podatkov in programskega paketa R. Gradivo $s$ seminarja je dostopno na konferenčni spletni strani.

Osrednji del konference je otvoril vabljeni predavatelj doc. dr. Michael Beißwenger $\mathrm{s}$ Tehniške univerze $\mathrm{v}$ Dortmundu s predstavitvijo nemške znanstvene mreže za raziskovanje internetne komunikacije Empirikom. V predavanju je izpostavil potrebo po prilagoditvi in razširitvi standardov za označevanje specifičnih elementov računalniško posredovane komunikacije tako na oblikoskladenjski ravni kot na ravni celotnega besedila. Posnetek vabljenega predavanja je dostopen na portalu Videolectures.net. 
Sledile so predstavitve 15 recenziranih izvirnih znanstvenih prispevkov, ki jih je pripravilo 23 avtorjev z 8 slovenskih in 3 tujih znanstvenih ustanov. Prispevki so bili razvrščeni v 4 tematske sklope. Prvi je bil posvečen gradnji virov in razvoju orodij za analizo računalniško posredovane komunikacije. V drugem sklopu so bili obravnavani prispevki, ki so karakteristike slovenščine $\mathrm{v}$ računalniško posredovani komunikaciji primerjali s pisno normo in govorjenim jezikom. Tretji sklop je zajemal prispevke s področja leksikografije, frazeologije in terminologije, četrti pa je bil namenjen sociolingvističnim raziskavam o regionalni zaznamovanosti jezika uporabniških spletnih vsebin, ekspresivnih prvinah v jeziku moških in žensk ter o žaljivem govoru. Prispevki so objavljeni v konferenčnem zborniku.

Zadnji dan konference je potekala tudi okrogla miza o podobi, vlogi in pomenu spletne slovenščine z naslovom »Slovenščina Janes: pogovorna, nestandardna, spletna ali spretna? «, ki jo je vodila dr. Špela Arhar Holdt (Trojina in FF UL), kot razpravljalci pa so sodelovali Marko Stabej (FF UL), Helena Dobrovoljc (ZRC SAZU in FH UNG), Simon Krek (IJS in FF UL), Polona Gantar (FF UL) in Damjan Popič (FF UL). Sklepno dejanje na konferenci, ki se je je udeležilo 45 udeležencev, je bila podelitev nagrade za najboljši študentski prispevek, ki ga je prejela Teja Rebernik z Univerze v Groningenu za prispevek z naslovom »Slovenščina pod palcem interneta: vezajne in dvozačetniške e-tvorjenke«. 
To delo je ponujeno pod licenco Creative Commons: Priznanje avtorstvaDeljenje pod enakimi pogoji 2.5 Slovenija.

This work is licensed under the Creative Commons Attribution ShareAlike 2.5 License Slovenia.

http://creativecommons.org/licenses/by-sa/2.5/si/

(c) (1) () () 